Birds of South America, pp. 116 117

4) EDWARD, E.P., 1972: A Field Guide to the Birds of Mexco. p. 249, col. pl. 22.

5) Hellmayr, C.E., 1938: Catalogue of Birds of the Americas. Pt. xi: $112 \sim 113$
6) 黒田長久, 1965: オオ八シのなかま「どうぶつと動 物園」上・中・下

7) Olrog, C.C. 1968: Las aves sudamericanas. p. 163, col. pl. 24 , fig. 359

(Received Nov. 8, 1973)

\title{
The Accidental Death of a Great Number of Seabirds on Gamo Coast, Miyagi Prefecture
}

\author{
Manabu T. ABE
}

魚網による海鳥類の事故死

阿部學*

\begin{abstract}
摘要: 最近日本各地の海岸に海鳥類の死体が多数打ち上げられ, 話題を投げかけているが, これらの うちタンカーの遭難による油污染など因果関係が明確なものは別として, 多くのものは農薬, $\mathrm{PCB}$, 疾 病などに基因しているのではないかといわれながらも決め手となる証拠がつかめなかった。

折しも 1972 年 4 月 15 日, 宮城県蒲生海岸に打ち上げられた約 60 羽のビロードキンクロ, クロガ モの死体の5ち 2 羽のビロードキンクロ（濯雄各 1 羽） が死因究明のため武石全慈1), 蓮尾嘉彪 ${ }^{2}$ の両 氏によって届けられた。

剖検の検果次の 7 点から推察して, 海中で採眲中魚網にひっかかり溺死したものと結論つりられた。

1) 肉づきも良く，健康体と考えられる，2）外傷がない，3）羽毛に油洉染の跡がない，4）後頭部と 首の皮下に著しいうっ血が見られる，5）各肺細胞に血液が充満している，これは酸素欠乏時にみられ る徵候である，6） 口腔, 食道, 砂のうに至るまで食物（ラフバンマメガニ）が充満している，7）死因 と直接結びつくような寄生虫, 疾病などは肉眼的には認められなかった。

今後沿岸漁業との関係において, 潜海性海鳥類の溺死は大きな問題となろら。

なお, ラフバンマメガニの同定の労をとられた東邦大学理学部生物学科の秋山章男助教授に謝意を表 する。
\end{abstract}

Great numbers of corpses, such as the Eastern Velvet Scoter, Melanitta fusca stejnegeri, the American Black Scoter, Melanitta nigra americana etc., were washed ashore on the Gamo Coast, near Sendai City, Miyagi Prefecture, in mid-April, 1972. About 60 corpses were found during a few days. The cause of death was unknown.

I received on April 17th two dead Eastern Velvet Scoters (a male and a female), which were picked up along the coast by Mr. Zenji TAKEISHI, a member of Miyagi Branch, The Japan Wildbird Society, Sendai, April 11, and carried to my office by $\mathrm{Mr}$. Yoshitake, Hasuo, a staff of the Japan Wildbird Society, Tokyo, for inquest.

As a result of microscopic autopsy, it is considered

* Institute for Wildlife, Government Forest Experiment Station, Meguro-ku, Tokyo. Zip Code 153

* 農林省林試保護部鳥獣第 1 研究室

1）日本野鳥の会宮城県支部

2）日本野鳥の会事務局 that the birds were caught in a fishing net in the midst of feeding and drowned. The reasons are as follows; 1) they were well-fed (they had normal body weights), 2) no injury was found on the surface of the bodies, 3) feathers were not polluted by oil, 4) hypodermic tissues of the cervix and the neck were heavily engorged with blood, 5) typical congestive edema caused by lack of oxygen was observed in each lung cell, 6) the buccal cavities, the oesophagi and the gizzards were filled with foods (only crabs, Pinnixa. raphbuni SAKAI were found) and 7) no parasite or pathological change which could have caused death was observed with the naked eye.

Above mentioned crabs are widely distributed around Japan. They live in water 30 40 meters deep.

Fishing nets could be a new significant problem for diving seabirds near the coast.

Measurements and the stomach contents are shnwn in Table 1 and 2 . 


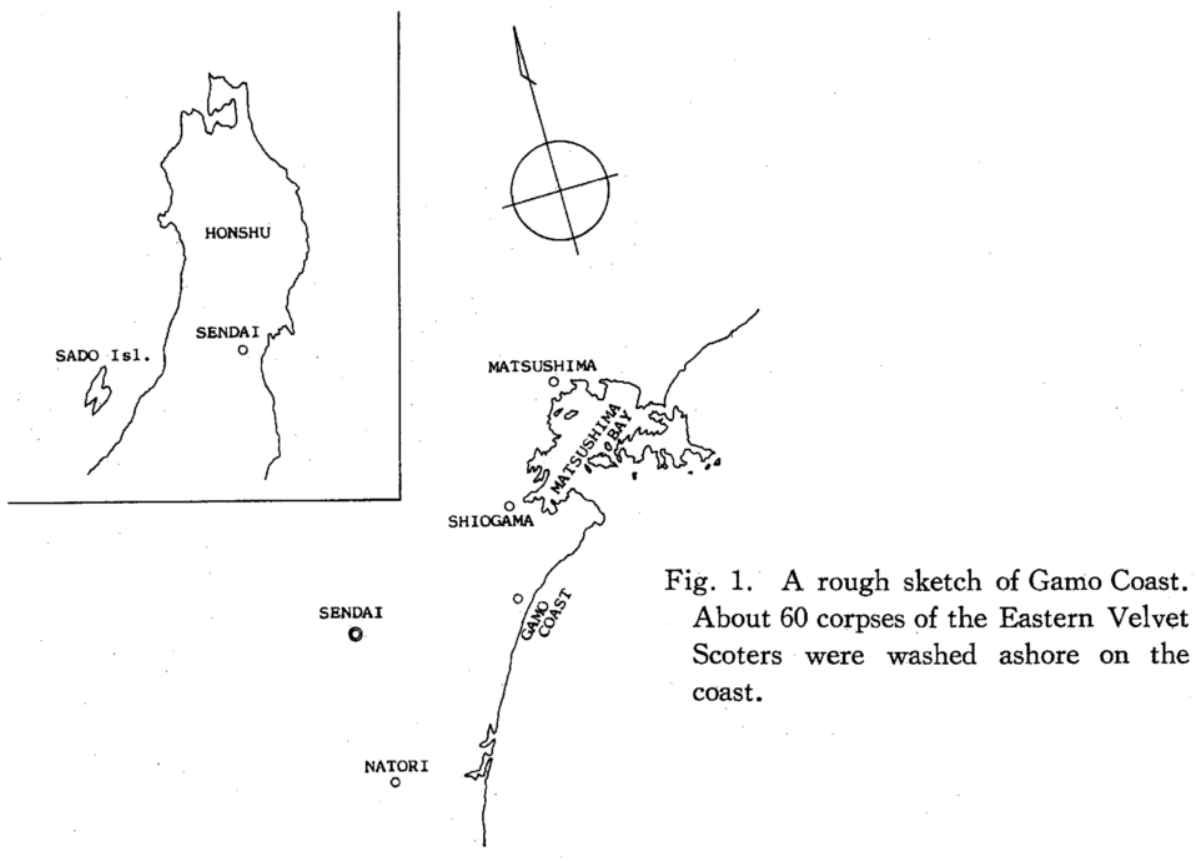

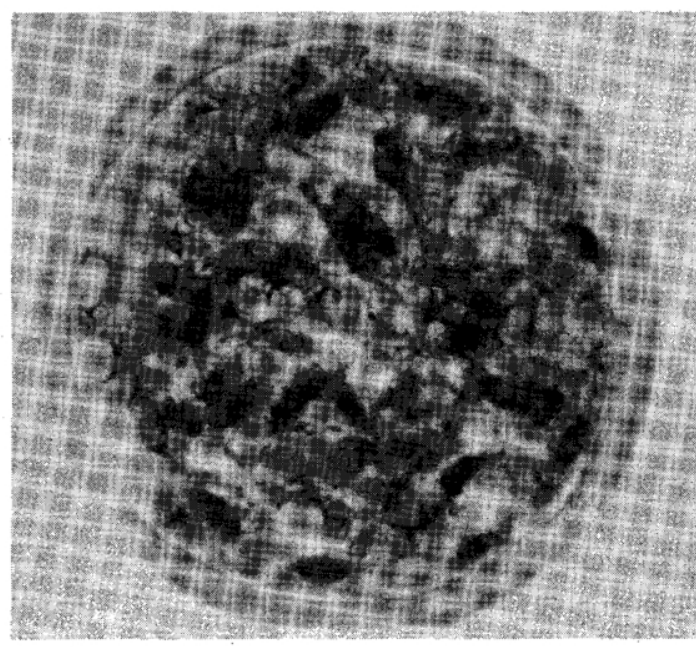

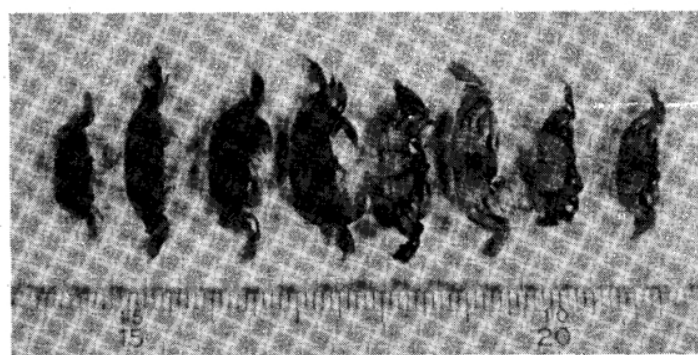

Fig. 2. Pinnixa raphbuni from the Eastern Velvet Scoters' stomach
Table 1. Measurement of Melanitta fusca stejnegeri

\begin{tabular}{l|c|c}
\hline & Male & Female \\
\hline Body weight & $1,667 \mathrm{~g}$ & $1,578 \mathrm{~g}$ \\
\hline Culmen & $47 \mathrm{~mm}$ & $45 \mathrm{~mm}$ \\
\hline Tarsus & $48 \mathrm{~mm}$ & $46 \mathrm{~mm}$ \\
\hline Wing & $275 \mathrm{~mm}$ & $263 \mathrm{~mm}$ \\
\hline Tail & $83 \mathrm{~mm}$ & $80 \mathrm{~mm}$ \\
\hline
\end{tabular}

Table 2. Stomach contents of Melanitta fusca stejnegeri. Many fragments of crabs, more than 100 crabs were found in each gizzard.

\begin{tabular}{c|c|c}
\hline & Male & Female \\
\hline Pinnixa raphbuni & 70 crabs & 40 crabs \\
\hline
\end{tabular}

\section{Acknowledgements}

Grateful acknowledgements are due to Mr. Akio AKIYAma, Assistant Professor, Institute of Biology, Faculty of Science, Toho University, for the identification of crabs. I am much indebted to Dr. Frank $\mathrm{H}$. Bell for his kindness in reading the present manuscript.

(Received Sept. 30, 1972) 